\title{
PROSPECT OF INDONESIA BLACK AND WHITE PEPPERS EXPORT
}

\author{
Tavi Supriana \\ Program Studi Agribisnis, Fakultas Pertanian \\ Universitas Sumatera Utara \\ e-mail: tavihutasuhut@yahoo.co.id \\ Chicka Willy Yanti \\ Program Studi Agribisnis, Fakultas Pertanian \\ Universitas Sumatera Utara \\ e-mail: chickawillyyanti@yahoo.co.id
}

\begin{abstract}
This study analyzes the behavior of pepper exports, consisting of black pepper and white pepper,to various destination countries. The results of this study showed that black pepper exports affected by the destination country's gross domestic product (GDP), the price of white pepper, the population of the country of destination and the exchange rate against the dollar. Meanwhile, white pepper exports affected by the destination country's GDP, the population of the country of destination, the price of black pepper, white pepper prices and the exchange rate against the dollar. The results also showed that black pepper and white pepper are not mutually substituted.
\end{abstract}

Keywords: pepper, exports, GDP, population, exchange rate

JEL Classificaiton Numbers: F14, F19

DOI:1 ttp://dx.doi.org/10.20885/ejem.vol5.iss1.art1

\begin{abstract}
Abstrak
Penelitian ini menganalisis perilaku ekspor lada, terdiri dari lada hitam dan lada putih, ke berbagai negara tujuan. Hasil penelitian ini menunjukkan bahwa ekspor lada hitam dipengaruhi oleh Pendapatan domestik bruto (PDB) negara tujuan, harga lada putih, populasi negara tujuan dan nilai tukar rupiah terhadap dolar. Sementara itu, ekspor lada putih dipengaruhi oleh PDB negara tujuan, populasi negara tujuan, harga lada hitam, harga lada putih dan nilai tukar rupiah terhadap dolar. Hasil penelitian juga menunjukkan bahwa lada hitam dan lada putih tidak saling bersubstitusi.
\end{abstract}

Keywords: Lada, ekspor, PDB, populasi, kurs

JEL Classificaiton Numbers: F14, F19

\section{INTRODUCTION}

Pepper is one of the herbal plants that b ecome one of the most important merchandise goods as well as the most important spice traded internationally. Pepper is one of the earliest types of spices traded in Europe. Pepper is used primarily in pharmaceuticals and food industries (Rismunandar, 2003). Pepper has been a worldwide commodity and has been receiv- ing worldwide concerns regarding the crop (John, 2012), the consumption (Nwaopara et al., 2007, Singletray, 2011), or the trade (see Kiong et al., 2010).

Indonesia is one of the world's largest producer of pepper. Pepper from Indonesia is exported in the form of black pepper and white pepper. In addition, Indonesian pepper also sold in powder, green pepper and oil pepper. Besides Indonesia, mojor pepper exporting countries are Brazil, 
Vietnam, India and Malaysia. The black pepper exports from major pepper producing countries are shown in Table 1 (For more on production and export performance of black pepper, please see Yogesh and Mokshapathy, 2013).

Figure 1 shows that the Indonesian black pepper exports have increased during the periods. The value of exports from 2003 to 2012 increased by $12.58 \%$ per year. The decline in the value of exports only occurred in 2004, 2005 and 2011. In 2011 , the value of these exports plummeted by $48.38 \%$ from the previous year. Figure 1 also shows that the Indonesian black pepper exports value is lower than that of Vietnam.

Figure 2 shows that from 2003 to 2008, Indonesia is the largest exporter of white pepper in the world. During 20032012, the average growth of export volume decreased by $4.07 \%$ per year but the value grew by $19.78 \%$ per year. In 2009 , the number of Indonesian exports of white pepper has been exceeded by the number of pepper export from Vietnam. This is an alarming condition considering Vietnam is a new country in spices export basiness.

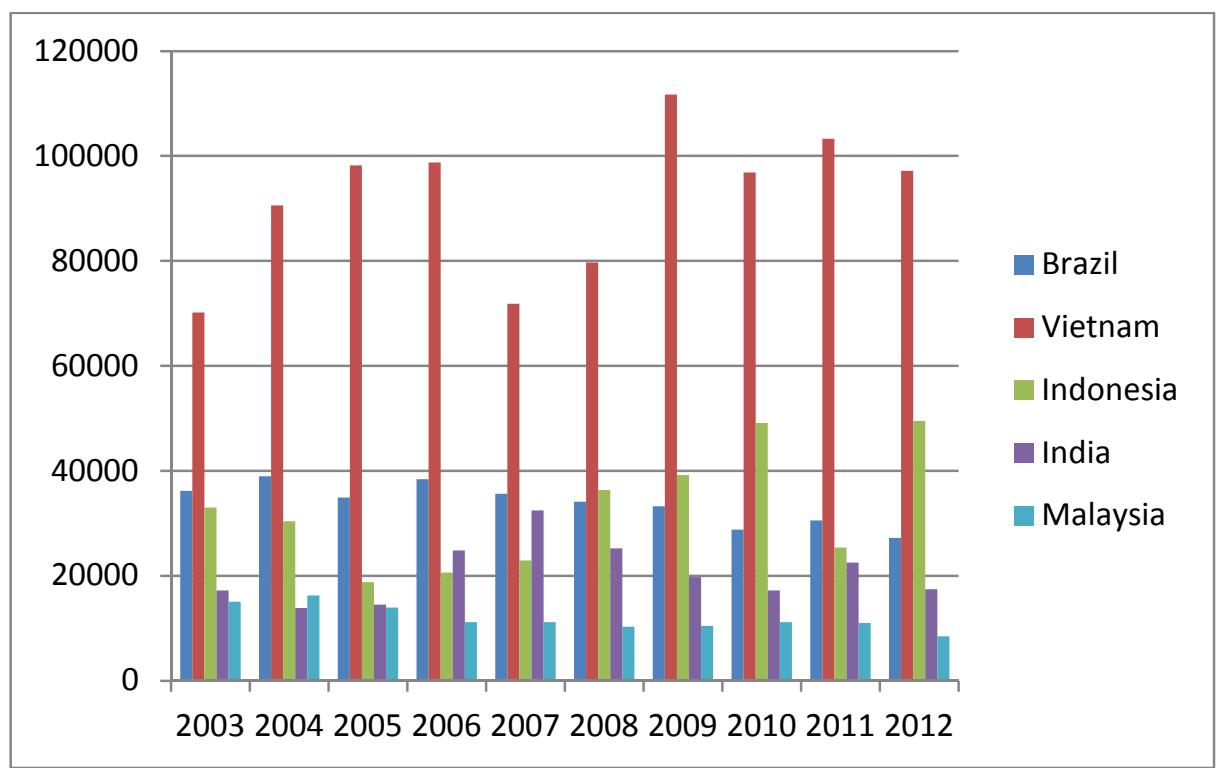

Source: IPC Statistical Yearbook 2012

Figure 1. Progress of Black Pepper Export

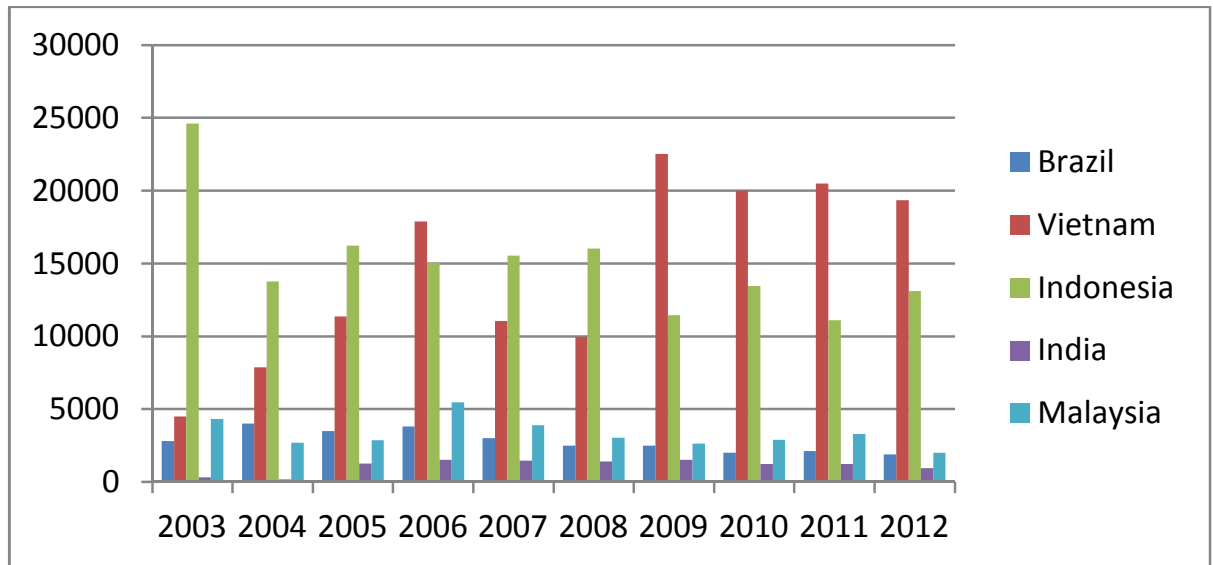

Source: IPC Statistical Yearbook 2012

Figure 2. Progress of White Pepper Export 


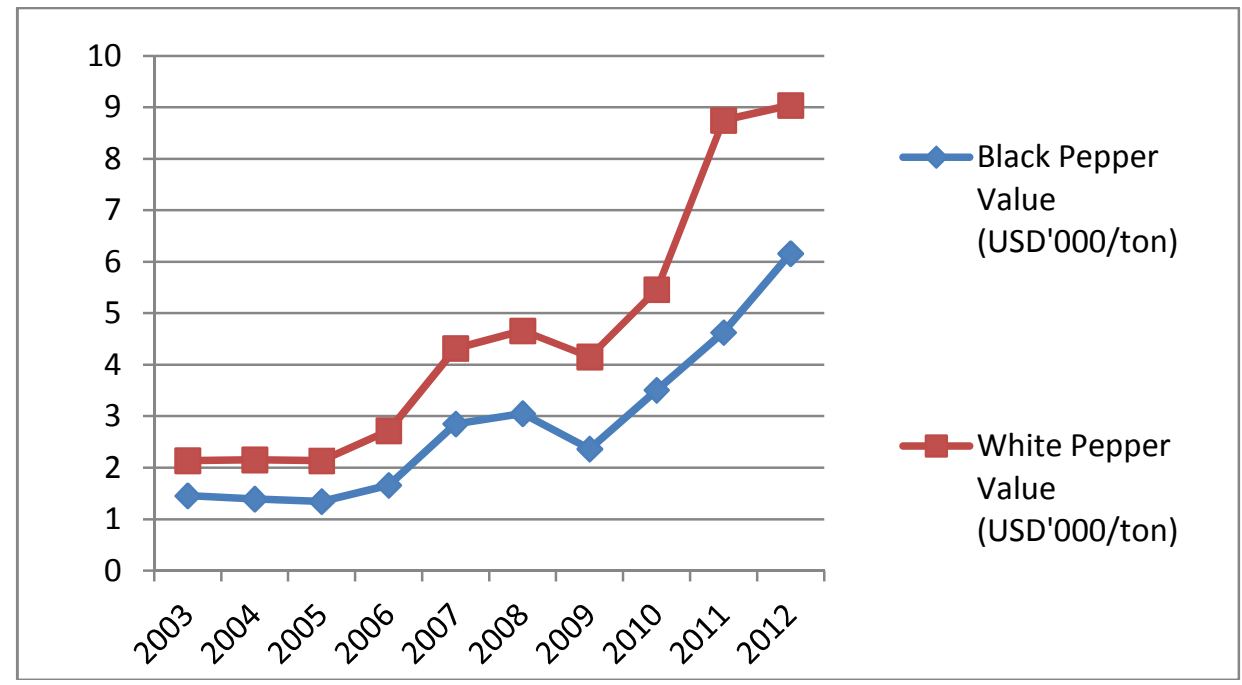

Source: IPC Statistical Yearbook 2012

Figure 3. Progress of Black and White Peppers Exports

Figure 3 shows that the value of Indonesian white pepper export exceeds the value those of black pepper. This is because both the number and the price of white pepper is bigger than those of black pepper. Throughout 2003-2012, black pepper export volume grew by an average of $12.58 \%$ per year, while its value grew by $20.66 \%$ per year. Meanwhile, the average growth of white pepper export volume during 20032012 decreased by $4.07 \%$ per year, eventhough the value grew by $9.78 \%$ per year.

Black pepper and white pepper are actually commodities that come from the same tree. The difference between both commodities is based on the difference in harvesting time and in processing. Black pepper is harvested when it is ripe-picking and dried with the skin without prior soaking process. White pepper are harvested when it is fully ripe and dried after soaking and stripping processes (Suwarto, 2002). In terms of utilization, both products have differences and similarities. Black pepper ingredient is widely used for traditional medicines such as Java herbal and liniment. The outer skin of black pepper can also be refined to produce etheric oils and typical scented resine. That is why black pepper are still produced by the farmers (Sarpian, 2003)
Indonesia exports black and white peppers to various countries. Indonesian pepper export destination countries have various characteristics depends on their income, population, and the value of their different currencies. These characteristics will affect trade between Indonesia and export destination countries. The income of export destination countries (Gross Domestic Product), the population of export destination countries, the price of pepper, and the exchange rate are expected to affect the export of Indonesian pepper.

According to Marwoto (2008), the phenomenon of substitution between black and white peppers also have an impact on developments in the pepper trade. The fact that black pepper prices are always cheaper than white peppers causes consumers choose black pepper. To analyze such phehonema, this paper conducts a research on factors influence black and white pepper exports from Indonesia to various destination countries.

Soebtrianasari (2008) analyzing the factors that affect the supply of white pepper from Indonesia and the factors thati nfluence the demand for white pepper in the international market. She found that the Indonesia export of white pepper to the United States is strongly influenced by the 
production of Indonesian white pepper, white pepper export amount of the previous year, and the real price of white pepper exports Meanwhile, white pepper exports to the Netherlands are only influenced by the real price of white pepper exports. United States white pepper import demand is affected by the US real income per capita and the number of the previous year imports of white pepper. Dutch white pepper import demand is influenced by the amount of the previous year imports of white pepper.

Marlinda (2008) analyzes the value of Revealed Comparative Advantage (RCA) to see the competitiveness of pepper. The results of the research showed that in 2006 the value of Indonesian pepper RCA is 14.32 but its competitiveness is still lower than that of Vietnam. To improve its competitiveness, Indonesia needs improve the quality and quantity of sales pepper to develop and increase exports of pepper.

Triana (2000), using time series data from the period 1969 to 1998 with the simultaneous equations, tests the influence of internal and external factors to the demand and supply of white pepper in the domestic and world markets. She found that the white pepper production is only responsive to changes in long-term productivity, but is not responsive to changes in the price of pepper, fertilizer prices, wages, interest rates, and harvest area. White pepper exports to Germany, the Netherlands, and Singapore are more responsive to changes in production levels compared with the change in the export price of white and black peppers, exchange rates, interest rates and the volume of re-exports of pepper of Singapore. Demand for white pepper imports of United States and the Netherlands are more responsive to changes in income compared to change in import prices of white and black peppers, the number of inhabitants, and the exchange rate. Japanese white pepper import demand is responsive to changes in the world price of black pepper. Meanwhile, the Germany and Singapore demand for imports of white pepper are responsive to changes in population.

Different from previous studies, this research builds a model for black pepper export and another model for white pepper export. With these two models, the paper will be able to identify the influence of the characteristics of export destination countries for the exports. This study focuses on the influence of external variables of export destinations and testing the substitution level of black and white peppers. In addition, this study uses a variety of observation to answer the latest phenomenon, namely a drastic decline in pepper exports during 2011-2012. This study also uses a different model from the previous ones, namely it uses a panel data model This model is expected to be able to show the best export destinations for black and white peppers.

\section{METHODS}

This study uses time series and cross section data. The time series data include annual data from the period of 2001 to 2012. The cross section data include eight of export destinations. To choose the country, this paper uses two criteria. First, it chooses countries that continuously trade pepper with Indonesia for 12 years. Second, it choosescountries that simultaneously import black and white peppers. This selection resulted in 8 countries, namely the United States, the Netherlands, Hong Kong, India, Germany, Japan, Singapore, and Taiwan. The variables expected to affect exports of pepper are real GDP of export destination countries, the price of real exports of black pepper and white pepper in the destination country, the population of export destination countries, and the exchange rate.

This paper estimates a panel data model i.e. a model that accommodates a combination of time series and cross section data. The estimation results of the panel data model is more efficient than that 
of regular models because it uses more observations. In addition, the use of panel data models can also reduce the effects of bias due to the increasing degrees of freedom. According to Veerbek (2008), the availability of repeated observations on the same unit allows economists to determine and estimate the model in a more complex and a more realistic ways than the model with cross section data only or models with time series data alone.

The approaches used in the analysis of panel data covering the pooled ordinary least squares, fixed effect model, and random effect model. Pooled least squares (PLS) models can be estimated using OLS. PLS assumes that both the intercept and the slope are constant. Such a model does not accommodate variations in individuals and time. However, constant intercept and slope are less realistic. To overcome these problems, we can use two types of panel data, namely the fixed effect model and random effect model. To accommodate variability in intercepts, we can use a dummy variable, so the model is also known as a Least square dummy variable (LSDV) model. The equation can be written as follows:

$$
\begin{aligned}
& Y_{i t}=a+\beta X_{i t}+\lambda_{2} W_{2 i}+\lambda_{3} W_{3 i}+\ldots \\
& +\lambda_{N} W_{N i}+\mu_{2} Z_{2 t}+\mu_{3} Z_{3 t}+\mu_{T} Z_{T t}+\varepsilon_{i t}
\end{aligned}
$$

where

$Y_{i t}$ is dependent variable for $i^{\text {th }}$ individual at $t^{\text {th }}$ time.

$X_{i t}$ is independent variable for $i^{\text {th }}$ individual at $t^{\text {th }}$ time.

$W_{i t}, Z_{i t}$ is dummy variable

$W_{i t}$ is 1 for indivual $i$, and $W_{i t}=0$ therwise; $i=1,2, \ldots, N$

$Z_{i t}$ is 1 ; for period $t$; and $Z_{i t}=0$ otherwise; $t$ is $1,2, \ldots \ldots T$

For the REM method, considering there are two components that have contributed to the formation of error, i.e. the individual and time, then the random error in REM also needs to be decomposed into an error for an individual component, a time component error and a combined error. The REM equation can formulated as follows

$Y_{i t}=a+\beta X_{i t}+\varepsilon_{i t} ; \quad \varepsilon_{i t}=u_{1}+v_{t}+W_{i t}$

where

$u_{1}$ is error cross section component

$v_{t}$ is error time-series component

$W_{i t}$ is combined error component

To choose the appropriate model, this paper uses three tests, namely the Chow, Hausman, and LM tests. Chow test was used to choose between the two models, namely pooled least squares and fixed effect models. After doing the Chow test, this paper conducts Hausman test to choose between the two models, namely the fixed effect model and random effect model. In the last step of model selection, this paper conducts a Lagrange Multiplier Test (LM test) to determine whether to use REM model or PLS model.

To analyze the behavior of exports of black and white peppers to the destination countries, this paper estimates the following regression model:

$X L H_{i j t}=a_{0}+a_{1} Y_{j}+a_{2} P L H_{x j}+a_{3} P L P_{x j}+$ $a_{4} P O P_{j}+a_{6} E R_{j}+e_{1}$

where

$X L H_{i j t}$ is Volume of black pepper export to country $j$ (tons)

$Y_{j} \quad$ is GDPof export destination country (USD billion)

$P L H_{x j}$ is Price of black pepper in export destination country (USD/ton)

$P L P_{x j}$ is Price of white pepper in export destination country (USD/ton)

$P O P_{j}$ is Population of export destination country (juta orang

$E R_{j}$ is Exchange rates (Rp/USD)

$t$ is Periods (year)

$a_{0}$ is constant

$a_{i}$ is koefisien regresi ( $\left.\mathrm{i}: 1,2,3, \ldots.\right)$

$e_{1} \quad$ is error term 
The determinant of white pepper export to the destination countries are

$$
\begin{aligned}
X L P_{i j t}= & b_{0}+b_{1} Y_{j}+b_{2} P L H_{x j}+b_{3} P L P_{x j} \\
& +b_{4} P O P_{j}+b_{5} E R_{j}+e_{2}
\end{aligned}
$$

where:

$X L H_{i j t}$ is Volume of white pepper export to country $j$ (tons)

$Y_{j} \quad$ is GDP of export destination country (USD billion)

$P L H_{x j}$ is Price of black pepper in export destination country (USD/ton)

$P L P_{x j}$ is Price of white pepper in export destination country (USD/ton)

$P O P_{j}$ is Population of export destination country (juta orang

$E R_{j}$ is Exchange rates (Rp/USD)

$t$ is Periods (year)

$a_{0}$ is constant

$a_{i}$ is koefisien regresi ( $\mathrm{i}: 1,2,3, \ldots$. )

$e_{2}$ is error term

Panel data includes more information, have a little collinearity between variables, have more degree of freedom, as well as more efficient, so that a panel data model does not require classical assumptions. For more discussion on panel data, please refer to Hsiao (2005), among others.

\section{RESULTS AND DISCUSSIONS}

\section{Progress of Indonesia Pepper Export}

Indonesia has been exporting pepper to various countries. These countries have a variety of characters that could affect exports. The pepper importing countries have different tastes of the black pepper and white pepper. This can be inferred from the export volumeof to these countries.

\section{Black and White Peppers Exports to the USA}

The USA imports peppers from Indonesia, Brazil, India, Vietnam and Malaysia. Indonesia is a major exporter of pepper to the United States. The progress of Indonesia black and white peppers exports to the United States in 2001 to 2012 are presented in Figure 4.

Figure 4 shows that the number of black pepper exports exceeds the number of white pepper exports. Black pepper exports increased by $10: 31 \%$ per year, while exports increased by $7.7 \%$ of white pepper per year.

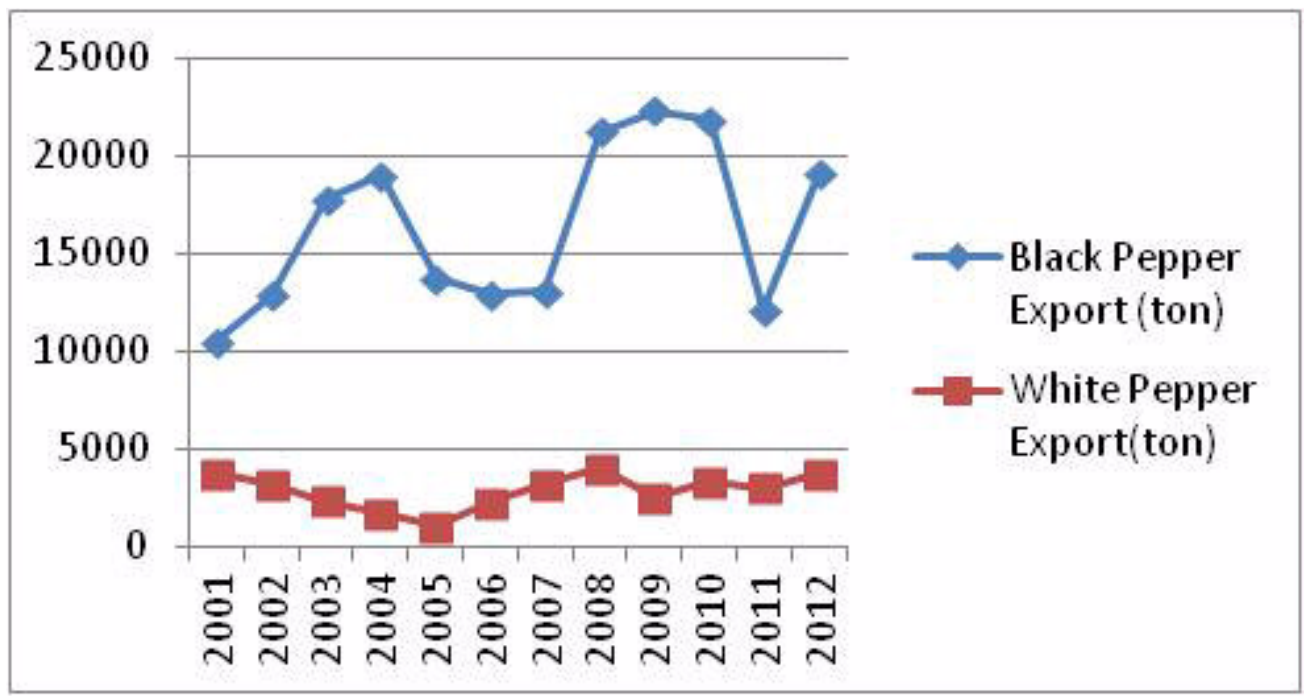

Source: IPC Statistical Yearbook 2012

Figure 4. Pepper Export to the USA 
Black and White Peppers Exports to the Netherlands

Netherlands imports peppers from mostly Vietnam, Brazil, Indonesia, India, Malaysia. The progress of Indonesia black and white peppers exports to Netherlands are presented in Figure 5. The number of Indonesian exports of white pepper to the Netherlands tend to fall throughout 2007-2012, approximately $13.94 \%$ per year. Meanwhile, the number of black pepper exports increased by $31.6 \%$ per year.

Black and White Peppers Exports to Hongkong

Hongkong imports peppers mostly from Indonesia, Malaysia, India, China, Vietnam.
The progress of Indonesia black and white peppers exports to Hongkong are presented in Figure 6. The number of black and white pepper exports to Hong Kong experienced a substantial decline in 2002. After 2002, the export of pepper tends to increase. The exports of black pepper increases by $33.04 \%$ per year, while white pepper export increase only $8.83 \%$ per year.

\section{Black and White Peppers Exports to India}

Eventhough India produces pepper, but India also imports pepper, mostly, from Sri Lanka, Indonesia, Vietnam, China, Brazil. The development of Indonesia exports of black pepper and white pepper to India are presented in Figure 7.

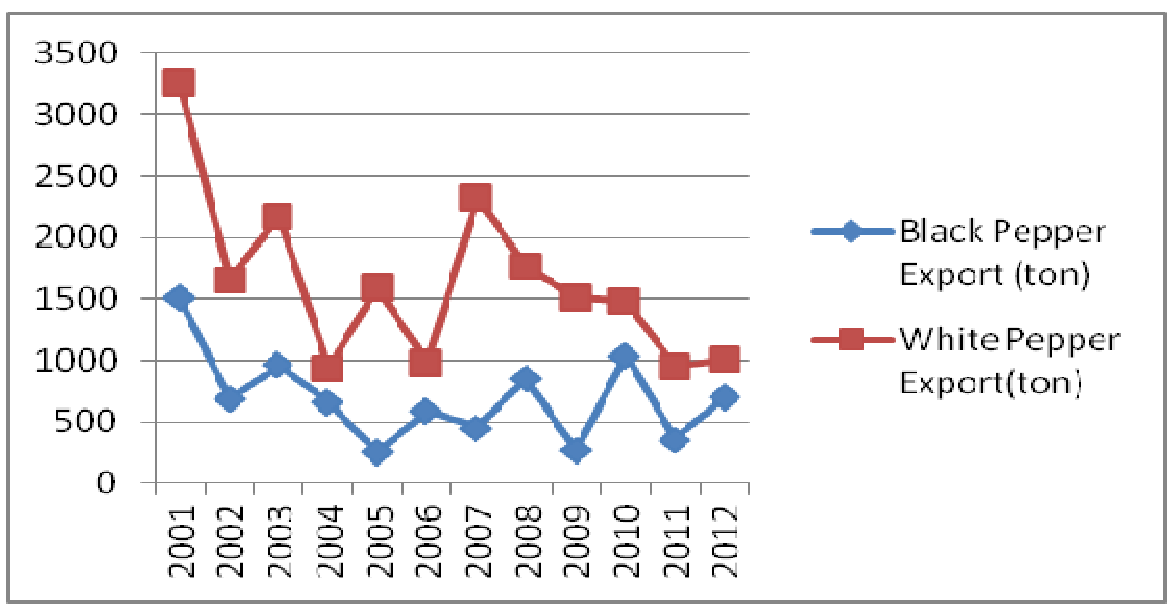

Source: IPC Statistical Yearbook 2012

Figure 5. Pepper Export to Netherlands

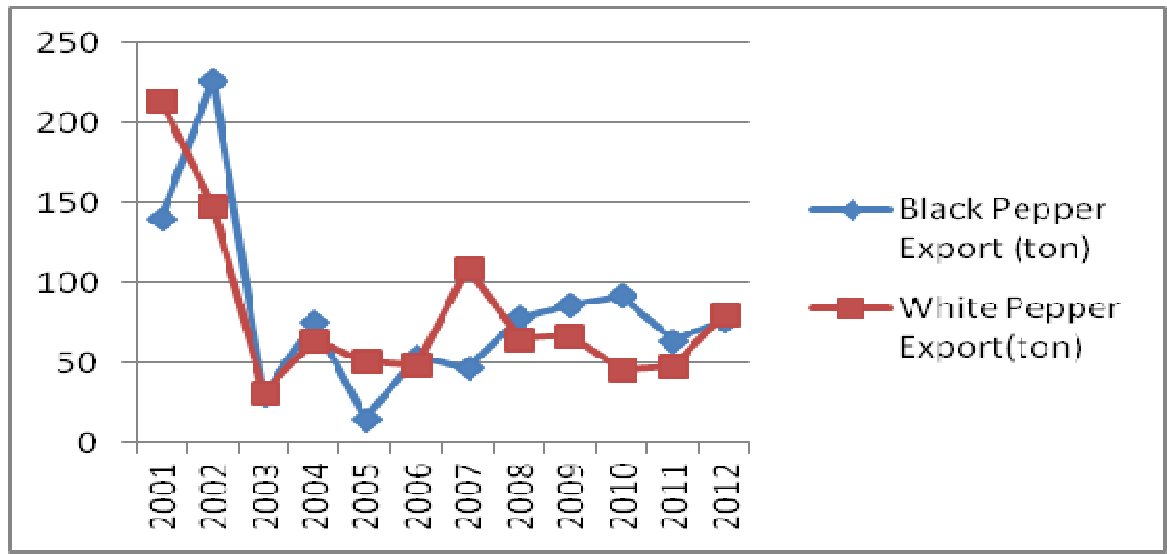

Source: IPC Statistical Yearbook 2012

Figure 6. Pepper Export to Hongkong 


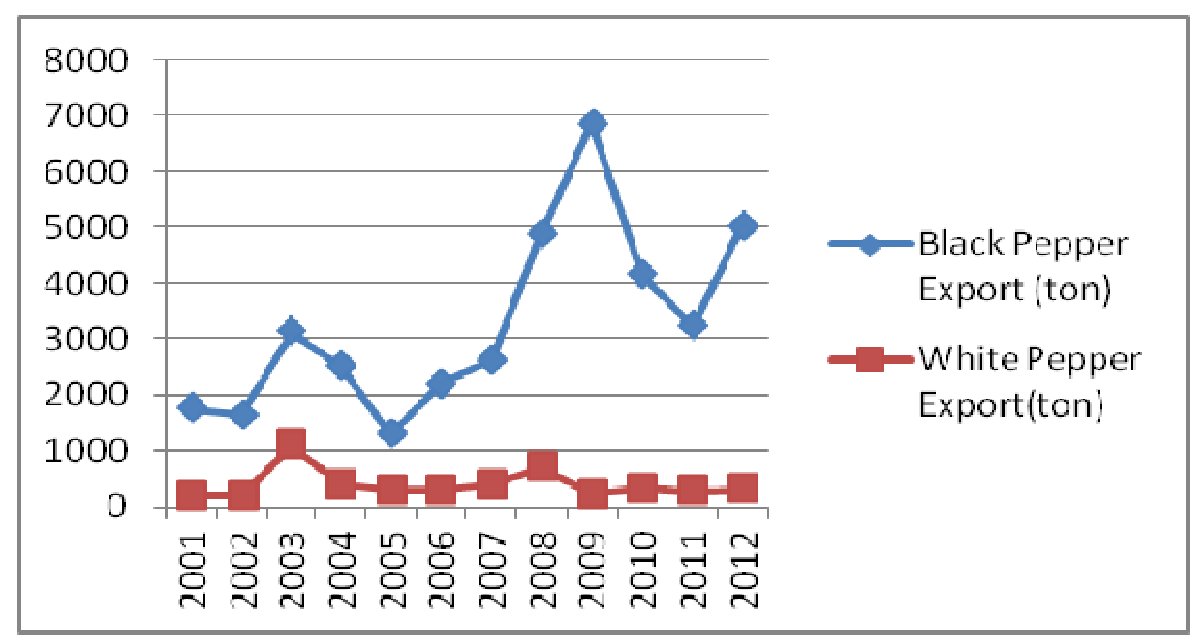

Source: IPC Statistical Yearbook 2012

Figure 7. Pepper Export to India

The number of Indonesian black pepper exports to India increased by $20.49 \%$ per year throughout 2001-2012. Meanwhile, in the same period, the number of Indonesian exports of white pepper to India increased by $8.01 \%$ per year

\section{Black and White Peppers Exports to Germany}

Based on the report of trade attaché Embassy in Berlin in 2013, Germany imports of pepper grows $11 \%$ per year throughout 2008-2012. Germany imported pepper mainly from Vietnam, Brazil, the Netherlands, Indonesia, India. The development of Indonesia exports of black pepper and white pepper to Germany are presented in Figure 8.

Indonesia white pepper exports to Germany increased by $6.38 \%$ per year during 2001-2010, and then drastically decreased by $42 \%$ in 2011 . The number of black pepper exports to Germany plummeted $35.27 \%$ in 2002 and $74 \%$ in 2005 . Indonesia black pepper export starts to increase in 2006 by $13.71 \%$ per year.

\section{Black and White Peppers Exports to Japan} Japan imported pepper mainly from Malaysia, Indonesia, India, Vietnam, Brazil. The development of Indonesia pepper exports to Japan are presented in Figure 9.

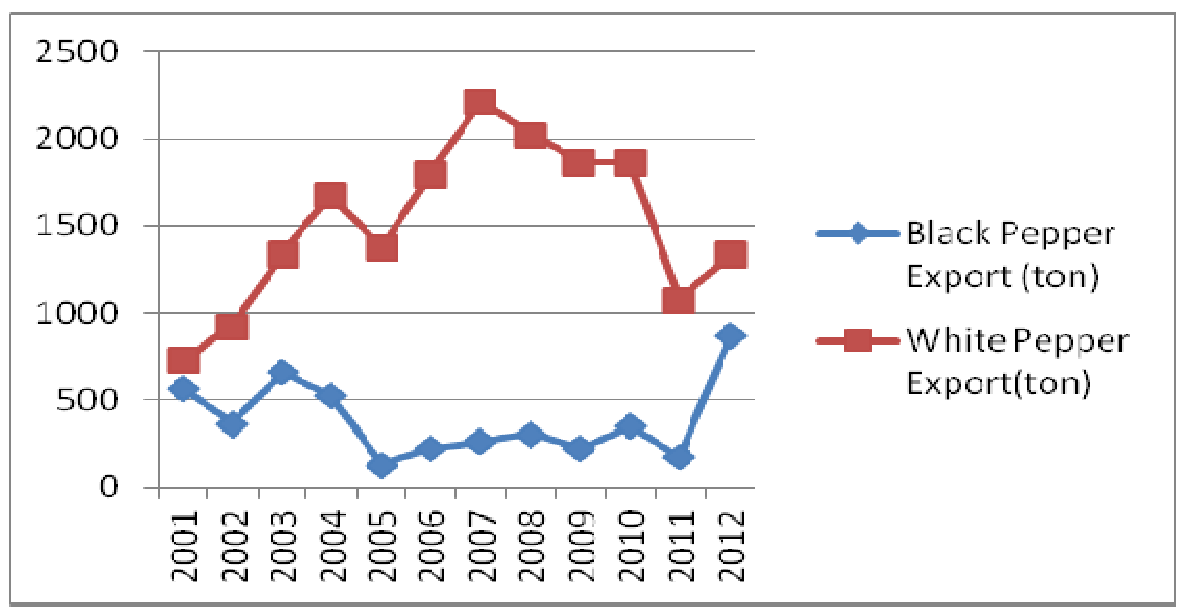

Source: IPC Statistical Yearbook 2012

Figure 8. Pepper Export to Germany 


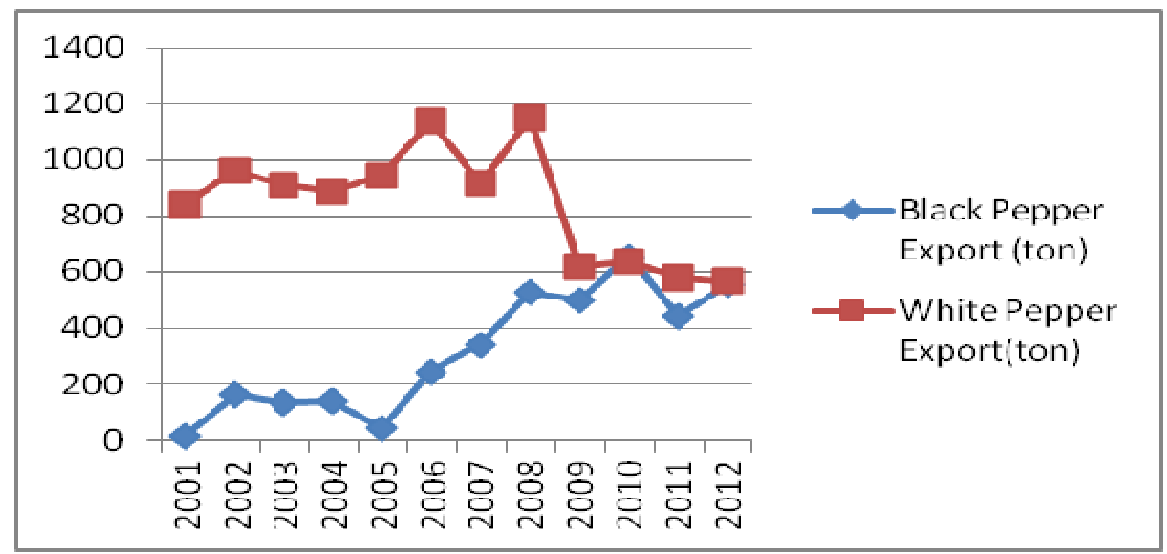

Source: IPC Statistical Yearbook 2012

Figure 9. Pepper Export to Japan

In 2005 , the number of Indonesia white pepper exports to Japan began to decline, while the amount of black pepper exports began to rise sharply. The number of white pepper exports fell by $13.51 \%$ per year throughout the last four years. Meanwhile, the number of black pepper exports increased by $48.64 \%$ per year.

\section{Black and White Peppers Exports to Singapore}

Singapore imports pepper mainly from Vietnam, Indonesia, Malaysia, India, Madagascar. Up to 2009, the export of pepper to Singapore is dominated by white pepper, but after 2009 the export of black pepper and white pepper are likely the same amount. The development of exports of black pepper and white pepper Indonesia to Singapore is presented in Figure 10.
Figure 10 shows that the number of white pepper exports fell by $19.83 \%$ per year throughout 2005-2009. Meanwhile, the number of black pepper exports increased by $22.73 \%$ per year. For the record, Singapore is processed pepper exporting countries. International Pepper Community states that the development of black pepper exports to Singapore in 2001 to 2012 fluctuated. A very interesting phenomenon is the tendency of white pepper exports that declines sharply.

\section{Black and White Peppers Exports to Taiwan}

Taiwan imported pepper mainly from Vietnam, Brazil, Indonesia, India, Malaysia. The development of Indonesia exports of black pepper and white pepper to Taiwan is presented in Figure 11.

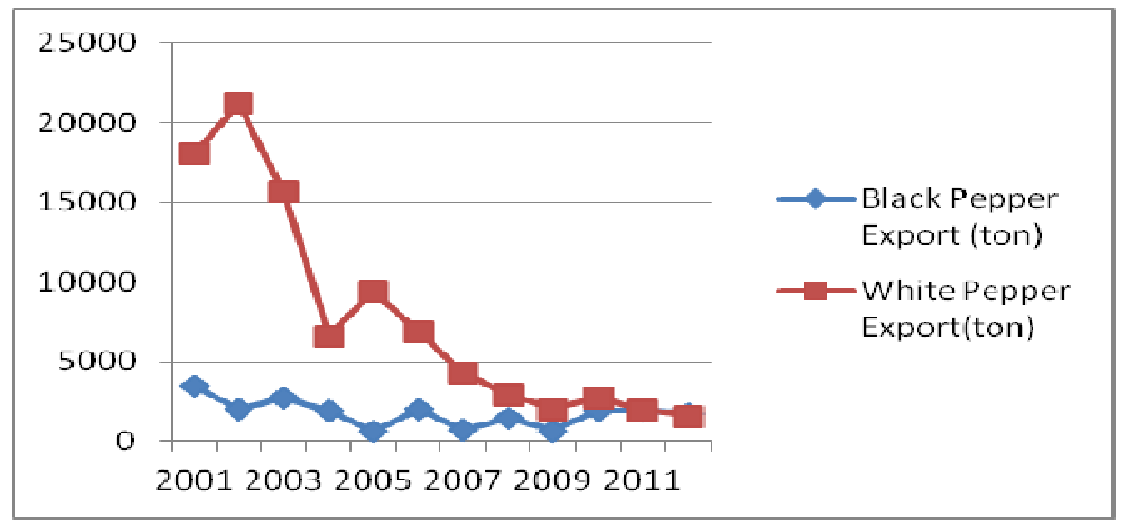

Source: IPC Statistical Yearbook 2012

Figure 10. Pepper Export to Singapore 


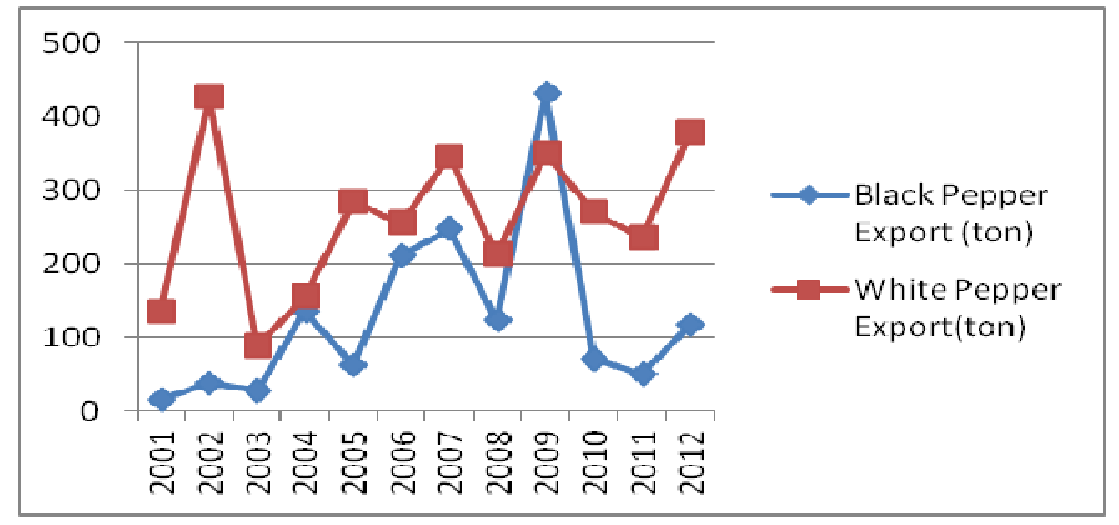

Source: IPC Statistical Yearbook 2012

Figure 11. Pepper Export to Taiwan

Figure 11 shows that the highest number of white pepper exports occurred in 2002 amounted to 426 tons with a value of USD561 thousand. The exports of black pepper was the highest in 2009 amounted to 430 tons with a value of USD157 thousand. Export of black pepper and white pepper increases and decreases simultaneously.

\section{Choosing the Panel Data Model}

This paper uses Chow test to determine the best model from two competing models, namely the Fixed Effects Model (FEM) and Random Effects Model (REM). Chow test results and the estimation are presented in Table 1.

The p-value of both F-test and chisquare for the equation of black pepper export is 0.0000 which allows us to reject $\mathrm{H} 0$. This means that FEM is better than PLS.
The estimation result of the FEM also has a higher $R^{2}(93.11 \%)$ than the PLS does (79.89). This means that the result of the FEM model is better than that of PLS. The same results were shown by the estimates of white pepper equation. The F-test and chi-square values of the model has a pvalue 0.0000 , and it has higher $R^{2}$ as well.

The next step is to choose the best model between two options, namely FEM with REM, by using the Hausman test. The estimates of REM and the Hausman test are presented in Table 2.

The p-value for black pepper export equation is 0.0077 so that $H_{0}$ is rejected at $1 \%$ significance level. The $R^{2}$ for FEM and REM are $93.1 \%$ and $46.8 \%$, respectively, indicating that the FEM is better the best one for the black pepper export equation.

Table 1: Chow Test

\begin{tabular}{lcccc}
\hline \multirow{2}{*}{ Equations } & PLS & FEM & \multicolumn{2}{c}{ Chow Test } \\
\cline { 2 - 5 } & $\mathrm{R}^{2}$ & $\mathrm{R}^{2}$ & F-test & Chi-Square \\
\hline Blac Pepper & 0,798 & 0,931 & 0,0000 & 0,0000 \\
\hline White Pepper & 0,076 & 0,590 & 0,0000 & 0,0000 \\
\hline
\end{tabular}

Table 2: Hausman Test on Black and White Peppers Equations

\begin{tabular}{lccc}
\hline \multirow{2}{*}{ Persamaan } & FEM & REM & Uji Hausman \\
\cline { 2 - 4 } & $\mathrm{R}^{2}$ & $\mathrm{R}^{2}$ & $p$-value \\
\hline Lada Hitam & 0.931 & 0.468 & 0.0077 \\
\hline Lada Putih & 0.590 & 0.121 & 0.3176 \\
\hline
\end{tabular}


Hausman test for white pepper export equation shows the p-value of 0.3176 (> 5\%) so that $H_{1}$ is rejected. Thus, the REM model is better than the FEM model for white pepper export equation. However, this result is not consistent with the results of the estimation. The estimation results indicate that the R2 for FEM and PLS models are $59 \%$ and $12.1 \%$, respectively. This indicates that the FEM model is better than the REM model. For such cases, when the number of time series observations is greater than the number of cross section observations, the recommended approach is the FEM one.

\section{Factors Affecting Export of Black Pepper}

The estimation results for black pepper exports are presented in Table 3. Variables significantly affecting black pepper export to the USA, the Netherlands, Hong Kong, India, Germany, Japan, Singapore, and Taiwan during 2001-2012 are GDP, the price of white pepper, population and exchange rates. Meanwhile, the price of black pepper does not affect the export of Indonesian black pepper. The $\mathrm{R}^{2}$ value of $85.4 \%$ and the $\operatorname{prob}(\mathrm{F}$ stat) of 0,00000 indicating the the model is a good one.

\section{Individual Effect of Destination Export of Black Pepper}

Individual effects (cross section effect) showed the different from each cross section. Individual effects for each export destination is obtained by adding the value of the constant equation of black pepper exportsto each individual coefficient:

$$
\underset{\text { Effect }}{\text { Individual }}=\text { Constant }+\begin{gathered}
\text { Individual } \\
\text { Coefficient }
\end{gathered}
$$

Individual effect of black pepper export destination country can be seen in table 4 .

The USA and Singapore are countries with positive individual effects. This means that both countries are the most potential black pepper export country destinations. If we assume that all the independent variables change, or constant, jointly, across countries and over time, the export destination country will give individual impact on Indonesia black pepper export as indicated by the value of the individual effect. The USA and Singapore are the export destination countries for Indonesia black pepper that will provide a positive individual influence, namely 3989.104 and 1368.23 , respectively.

Table 3: Estimation Result of Factors Affecting Black Pepper Export*

\begin{tabular}{lcc}
\hline Variable & Coefficient & Probability \\
\hline C & -1880.053 & 0.0272 \\
GDP & 0.694987 & 0.0003 \\
Price of Black Pepper Export (PLH) & 0.006969 & 0.8055 \\
Price of White Pepper Export (PLP) & -0.053904 & 0.0035 \\
Population (POP) & 12.58262 & 0.0001 \\
Exchange Rates (ER) & 0.043683 & 0.0050 \\
Fixed Effect (Cross) & & \\
The USA & 5869.667 & \\
The Netherlands & 1682.426 & \\
Hongkong & 1490.113 & \\
India & -9668.895 & \\
Germany & -902.0474 & \\
Japan & -2916.880 & \\
Singapore & 3248.801 & \\
Taiwan & 1196.814 & \\
$\quad \mathrm{R}^{2}=0.854028$, Adjusted $\mathrm{R}^{2}=0.832924$, Prob (F-Stat) $=0.000$ \\
\hline
\end{tabular}

*Notes: FEM Methods with the Weight of Cross Section SUR 
Table 4: Individual Effect of Export Destination Countries

\begin{tabular}{lc}
\hline Country & Individual Effect \\
\hline The USA & 3989.104 \\
The Netherlands & -198.137 \\
Hongkong & -390.45 \\
India & -11549.5 \\
Germany & -2782.61 \\
Japan & -4797.44 \\
Singapore & 1368.238 \\
Taiwan & -683.749 \\
\hline
\end{tabular}

\section{Factors Influencing White Pepper Export}

The estimation results of Indonesia white pepper export is in Table 5. Variables that affect the Indonesia export of black pepper and white pepper are GDP, prices of black and white peppers, population, and the exchange rate against the dollar.
The Individual Effect of White Pepper Export Destination Countries

The individual effect of each Indonesia export destination country is in Table 6 .

Table 5. Estimation Result of Factors Affecting White Pepper Export*

\begin{tabular}{lcc}
\hline \multicolumn{1}{c}{ Variable } & Coefficient & Probability \\
\hline C & 709,4278 & 0,1288 \\
GDP & 1,391079 & 0,0000 \\
Harga Ekspor Lada Putih (PLP) & $-0,320052$ & 0,0001 \\
Harga Ekspor Lada Hitam (PLH) & 0,360322 & 0,0000 \\
Populasi (POP) & 9,621072 & 0,0000 \\
Nilai tukar (ER) & $-0,411170$ & 0,0000 \\
Fixed Effect (Cross) & & \\
The USA & -12934.26 & \\
The Netherlands & 4457.718 & \\
Hongkong & 3612.029 & \\
India & -7613.155 & \\
Germany & 751.3863 & \\
Japan & -3288.265 & \\
Singapore & 11504.31 & \\
Taiwan & 3510.240 & \\
$\mathrm{R}^{2}=0,885101$, Adjusted R ${ }^{2}=0,868489$, Prob (F-Stat) $=0.000$ & \\
\hline \multicolumn{2}{c}{$*$ Notes: FEM Methods with the Weight of Cross Section SUR }
\end{tabular}

Table 6. Individual Effect of Exporting Destination Countries

\begin{tabular}{lc}
\hline Country & Individual Effect \\
\hline The USA & -12224.8 \\
The Netherlands & 5167.146 \\
Hongkong & 4321.457 \\
India & -6903.73 \\
Germany & 1460.814 \\
Japan & -2578.84 \\
Singapore & 12213.74 \\
Taiwan & 4219.668 \\
\hline
\end{tabular}


The country with the biggest individual effect is Singapore, while the country with the smallest individual effect is the USA. The Netherlands, Hongkong, Germany, Singapore and Taiwan have positive individual effects which means that they are the best white pepper export destination countries.

\section{CONCLUSION}

This study found that the Gross Domestic Product (GDP) of export destination countries, the population of export destination countries, and the exchange rate against the dollar positively affect the export of Indonesian black pepper. Indonesian white pepper prices in the country of destination negatively affect Indonesian exports of black pepper in the destination country. Meanhile, the Indonesian black pepper prices in the destination country does not significantly influence the Indonesian black pepper exports in the destination country.

GDP of the destination country, Indonesian black pepper prices in the destination country, and the population of the destination country have a positive effect on Indonesia white pepper export. Indonesian white pepper prices in the destination country and exchange rates negatively affect Indonesian white pepper export.

The best export destination countries for Indonesian black pepper are the USA and Singapore, while the best export destination countries for Indonesian white pepper are The Netherlands, Hong Kong, Germany, Singapore and Taiwan. This paper also found that black and white peppers are not subtitute each other.

\section{REFERENCES}

Hsiao, C. (2005), "Why Panel Data?" IEPR Working Paper No. 05.33, Institute of Economic Policy Research, University of Southern California.

IPC Statistical Yearbook 2012, Can be accessed from http://www.ipcnet.org/n/psy2012/

John, G.G. (2012), "Pepper Crop Report," A Paper presented at the ESA General Assembly Meeting, June 2012, Gothenburg, Sweden

Kiong, W.S., K.A. Rahim \&and M.N. Shamsudin (2010), "Long-run Determinants of Export Supply of Sarawak Black and White Pepper: An ARDL Approach," Global Economy and Finance Journal, 3(1), Pp. 78-87

Marlinda, B. (2008), Analisis Daya Saing Lada Di Pasar Internasional, Skripsi, Program Studi Ekonomi Pertanian dan Sumberdaya. Fakultas Pertanian. IPB, Bogor.

Marwoto, P.B. (2008), Pemerintah Kabupaten Bangka: Permintaan dan Penawaran Lada Bangka di Pasar Internasional, Bangka Belitung, Juni, diakses 20 April 2014 dari http://www bangka. oo.id/artikel.php?id artikel=10.

Nwaopara, A.O., M.A.C. Odike, U. Inegbenebor and M.I. Adoye (2007), "The Combined Effects of Excessive Consumption of Ginger, Clove, Red Pepper and Black Pepper on the Histology of the Liver," Pakistan Journal of Nutrition, 6(6), 524-527.

Rismunandar (2003), Lada: Budi Daya dan Tata Niaga, Penebar Swadaya, Jakarta.

Sarpian, T. (2003), Budi Daya Lada dengan Tajar Hidup, Penebar Swadaya, Jakarta.

Singletary, K. (2011), "Red Pepper Overview of Potential Health Benefits," Nutrition Today, 46(1), 33-47. 
Soebtrianansari, D. (2008), Analisis Penawaran dan Permintaan Lada Putih Indonesia di Pasar Internasional, Skripsi, Program Sarjana Ekstensi Manajemen Agribisnis, Fakultas Pertanian, Institut Pertanian Bogor, Bogor

Suwarto (2002), Lada (Piper Nigrum Linn.), Jurusan Budidaya Pertanian, Fakultas Pertanian, Institut Pertanian Bogor, Bogor.

Triana, F. (2000), Dampak Perubahan Faktor Internal dan Eksternal Terhadap Permintaan dan Penawaran Lada Putih di Pasar Domestik dan Dunia, Tesis, Program Pascasarjana, Ilmu Ekonomi Pertanian, Fakultas Pertanian, Institut Pertanian Bogor, Bogor.

Veerbek, M. (2008), A Guide to Modern Econometrics, $3^{\text {rd }}$, John Willey and Sons Ltd. England.

Yogesh, M.S. and S. Mokshapathy (2013), "Production and Export Performance of Black Pepper," International Journal of Humanities and Social Science Invention, 2(4), $36-44$.

Yogesh, M.S. and S. Mokshapathy (2014), "Indian Export Scenario of Pepper Oil and Pepper Oleoresin," International Journal of Business and Management, 2(2), 36-41. 